\title{
Effect of beta blockers on the incidence of atrial fibrillation in elderly patients after abdominal surgery
}

\author{
Gennaro Pagano ${ }^{1 *}$, Dario Leosco ${ }^{1}$, Nicola Ferrara ${ }^{1,2}$, Nicola Rocco $^{3}$, Corrado Rispoli $^{4}$, Loredana lannone ${ }^{5}$, \\ Serena Testa ${ }^{4}$, Rita Compagna ${ }^{6}$, Antonello Accurso ${ }^{6}$, Bruno Amato ${ }^{6}$
}

From 26th National Congress of the Italian Society of Geriatric Surgery

Naples, Italy. 19-22 June 2013

\section{Aim of the study}

To determine whether treatment with Beta Blockers during abdominal surgery would reduce the incidence of post-operative Atrial Fibrillation (AF).

\section{Background}

Post operative AF is a common problem in patients following surgery. The incidence of such arrhythmia has been reported to range from $20-35 \%$ and increase to the age and to presence of comorbidities [1-3]. Also, AF is related to many complications and it is still debated what is the best interventions, especially in the elderly [4]. Sympathetic nervous system activation is strictly related to surgery stress [5] and treatment with Beta Blockers may reduce this overactivation that predispose to AF occurence [6-10].

\section{Methods}

A pilot study was conducted with 30 elderly patients (age > 65 years) who underwent abdominal surgery (right emicolectomy, sigmoidectomy and anterior rectal resection). They were randomized to control (ctr) ( $\mathrm{n}=$ 14) and Beta Blockers (beta) $(n=16)$ groups. Before surgery all elderly patients have been taking Beta Blockers (for hypertension or heart failure). During and after surgery only the beta group received the medication. Both groups were well matched and had the same demographic and clinical characteristics.

\footnotetext{
* Correspondence: gennaropagano85@hotmail.com

'Department of Translational Medical Sciences, Federico II University of Naples, Naples, Italy

Full list of author information is available at the end of the article
}

\section{Results}

After surgery 5 patients of ctr group and in 1 patients of beta group developed AF $(\mathrm{p}<0.001)$. All patients with AF occurrence were $>75$ years old.

\section{Conclusions}

Beta Blockers could not be stopped during abdominal surgery in elderly patients (with hypertension or heart failure) because significantly reduce the incidence of post-operative AF. Moreover, the link between the older age and AF occurrence is confirmed also in this population.

\section{Authors' details \\ ${ }^{1}$ Department of Translational Medical Sciences, Federico II University of Naples, Naples, Italy. " ${ }^{2}$ Salvatore Maugeri" Foundation, IRCCS Scientific Institute of Telese Terme, Benevento, Italy. ${ }^{3}$ Department of Biomedical, Surgical and Dental Sciences, University of Milan, Milan, Italy. ${ }^{4}$ Department of General Surgery - ASL NA1, Cardinale Ascalesi Hospital, Naples, Italy. ${ }^{5}$ Department of General Surgery, Fatebenefratelli Hospital, Benevento, Italy. ${ }^{6}$ Department of General, Geriatric, Oncologic Surgery and Advanced Technologies, Federico II University of Naples, Naples, Italy.}

Published: 16 September 2013

\section{References}

1. Rengo F, Parisi V, Rengo G, Femminella GD, Rengo C, Zincarelli C, Pagano G, Festa G, De Lucia C, Leosco D: Instruments for geriatric assessment: new multidimensional assessment approaches. JOURNAL OF NEPHROLOGY 2012, 25:73-78, ISSN: 1121-8428, doi: 10.5301/jn.5000164.

2. Pilotto A, Addante F, Franceschi M, Leandro G, Rengo G, D'Ambrosio P, Longo MG, Rengo F, Pellegrini F, Dallapiccola B, Ferrucci L: A Multidimensional Prognostic Index (MPI) based on a Comprehensive Geriatric Assessment Predicts Short-Term Mortality in Older Patients with Heart Failure. Circulation: Heart Failiure 2010, 3:14-20.

3. Rengo F, Leosco D, lacovoni A, Rengo G, Golino L, Borgia F, De Lisa G, Beneduce F, Senni M: Epidemiology and risk factors for heart failure in the elderly. Italian heart journal : official journal of the Italian Federation of Cardiology 2004, 5(Suppl 10):9S-16S.

4. Rengo G, Pagano G, Squizzato A, Moja L, Femminella GD, de Lucia C, Komici K, Parisi V, Savarese G, Ferrara N, Perrone-Filardi P, Leosco D: Oral 
anticoagulation therapy in heart failure patients in sinus rhythm: a systematic review and meta-analysis. PloS One 2013, 8(1):e52952, doi:10.1371/journal.pone.0052952.

5. Paolillo S, Rengo G, Pagano G, Pellegrino T, Savarese G, Femminella GD, Tuccillo, Boemio A, Attena E, Formisano R, Petraglia L, Scopacasa F, Galasso G, Leosco D, Trimarco B, Cuocolo A, Perrone-Filardi P: Impact of Diabetes Mellitus on Cardiac Sympathetic Innervation in Patients With Heart Failure. A lodine-123 meta-iodobenzylguanidine (1123MIBG) Scintigraphic Study. Diabetes Care 2013.

6. Rengo G, Lymperopoulos A, Zincarelli C, Femminella Gd, Liccardo D, Pagano G, de Lucia C, Cannavo A, Gargiulo P, Ferrara N, Perrone Filardi P, Koch Wj, Leosco D: Blockade of beta-adrenoceptors restores the GRK2mediated adrenal alpha(2) -adrenoceptor-catecholamine production axis in heart failure. BRITISH JOURNAL OF PHARMACOLOGY 2012, 166:2430-2440, ISSN: 1476-5381, doi: 10.1111/j.1476-5381.2012.01972.x.

7. Rengo G, Zincarelli C, Femminella GD, Liccardo D, Pagano G, de Lucia C Altobelli GG, Cimini V, Ruggiero D, Perrone-Filardi P, Gao E, Ferrara N, Lymperopoulos A, Koch WJ, Leosco D: Myocardial beta(2) -adrenoceptor gene delivery promotes coordinated cardiac adaptive remodelling and angiogenesis in heart failure. BRITISH JOURNAL OF PHARMACOLOGY 2012, 166:2348-2361, ISSN: 1476-5381, doi: 10.1111/j.1476-5381.2012.01954.x.

8. Rengo G, Perrone-Filardi P, Femminella GD, Liccardo D, Zincarelli C, de Lucia C, Pagano G, Marsico F, Lymperopoulos A, Leosco D: Targeting the beta-adrenergic receptor system through $\mathrm{G}$-protein-coupled receptor kinase 2: a new paradigm for therapy and prognostic evaluation in heart failure: from bench to bedside. CIRCULATION. HEART FAILURE 2012, 5:385-391, ISSN: 1941-3289, doi: 10.1161/CIRCHEARTFAILURE.112.966895.

9. Rispoli C, Rocco N, lannone L, Amato B: Developing guidelines in geriatric surgery: role of the grade system. BMC Geriatrics 2009, 9(SUPPL.1):A99.

10. Leosco D, Rengo G, laccarino G, Golino L, Marchese M, Fortunato F, Zincarelli C, Sanzari E, Ciccarelli M, Galasso G, Altobelli GG, Conti V, Matrone G, Cimini V, Ferrara N, Filippelli A, Koch WJ, Rengo F: Exercise promotes angiogenesis and improves $\beta$-adrenergic receptor signalling in the post-ischaemic failing rat heart. Cardiovascular Research 2008, 30(3).

doi:10.1186/1471-2482-13-S1-A32

Cite this article as: Pagano et al.: Effect of beta blockers on the incidence of atrial fibrillation in elderly patients after abdominal surgery. BMC Surgery 2013 13(Suppl 1):A32.

\section{Submit your next manuscript to BioMed Central and take full advantage of:}

- Convenient online submission

- Thorough peer review

- No space constraints or color figure charges

- Immediate publication on acceptance

- Inclusion in PubMed, CAS, Scopus and Google Scholar

- Research which is freely available for redistribution

Submit your manuscript at www.biomedcentral.com/submit 